\title{
COMPLICATIONS IN THREE LUMBAR ARTHRODESIS TECHNIQUES: TLIF, MITLIF, PLIF
}

\author{
COMPLICAÇÕES EM TRÊS TÉCNICAS DE ARTRODESE LOMBAR: TLIF, MITLIF, PLIF \\ COMPLICACIONES EN TRES TÉCNICAS DE ARTRODESIS LUMBAR: TLIF, MITLIF, PLIF
}

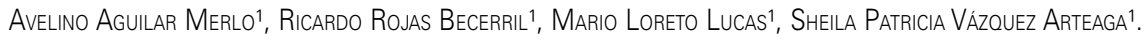

1. Hospital Central Norte de Petróleos Mexicanos, Spine Clinic, San Antonio, Ciudad de México, D.F.

\begin{abstract}
Objective: To determine that minimally invasive transforaminal lumbar fusion has fewer complications of chronic lumbar instability compared with traditional open techniques. Methods: Retrospective, observational study of 132 patients with grade I and II lumbar spondylolisthesis with advanced disc degeneration. Forty-five patients operated by minimally invasive transforaminal lumbar interbody fusion (MITLIF), 45 patients operated by posterior lumbar interbody fusion (PLIF) and 42 patients operated by open transforaminal lumbar interbody fusion (TLIF). Results: Four patients had incidental durotomy, two in the TLIF group and two in the PLIF group. There were no cases of incidental durotomy in the minimally invasive transforaminal access group. No patient in the study presented an inadequate screw position, the lowest mean bleeding occurred in the group of minimally invasive instrumentation of one and two levels. There were $6.6 \%$ of infections for PLIF group and none in the other two groups. Conclusions: Arthrodesis techniques are not free of complications, however, the frequency is lower with minimally invasive techniques. Nonetheless, it requires training and does not dispense the need for a learning curve for the spine surgeon compared to open lumbar fusion techniques.
\end{abstract}

Keywords: Spondylolisthesis, Intervertebral disc degeneration, Decompression surgical; Arthrodesis.

\section{RESUMO}

Objetivo: Determinar que a artrodese lombar transforaminal minimamente invasiva tem menos complicações de instabilidade lombar crônica em comparação com técnicas abertas tradicionais. Métodos: Estudo retrospectivo observacional em 132 pacientes com espondilolistese lombar de grau I e II com degeneração avançada de disco. Quarenta e cinco pacientes operados por artrodese lombar intersomática transforaminal minimamente invasiva (MITLIF, minimally invasive transforaminal lumbar interbody fusion), 45 pacientes operados por artrodese lombar intersomática por via posterior (PLIF, posterior lumbar interbody fusion) e 42 pacientes operados por artrodese intersomática lombar transforaminal (TLIF, transforaminal lumbar interbody fusion) aberta. Resultados: Quatro pacientes tiveram durotomia acidental, dois do grupo TLIF e dois do grupo PLIF. Não houve casos de durotomia acidental no grupo acesso transforaminal minimamente invasivo. Nenhum paciente estudado apresentou posição inadequada do parafuso, o menor sangramento médio ocorreu no grupo de instrumentação minimamente invasiva em um e dois níveis. Houve 6,6\% de infecções no grupo PLIF e nenhuma nos outros dois grupos. Conclusões: As técnicas de artrodese não são isentas de complicações, no entanto, a frequência é menor com as técnicas minimamente invasivas. Contudo, requer treinamento e não dispensa a necessidade de uma curva de aprendizado para o cirurgião de coluna, em comparação com técnicas de fusão lombar abertas.

Descritores: Espondilolistese, Degeneração do disco intervertebral; Descompressão cirúrgica; Artrodese.

\section{RESUMEN}

Objetivo: Determinar que la artrodesis lumbar transforaminal mínimamente invasiva tiene menor número de complicaciones de inestabilidad lumbar crónica en comparación a las técnicas abiertas tradicionales. Métodos: Se realizó un estudio retrospectivo observacional en 132 pacientes con espondilolistesis lumbar de grado / y ll con degeneración discal avanzada. Cuarenta y cinco pacientes operados por artrodesis lumbar intersomática transforaminal mínimamente invasiva (MITLIF, minimally invasive transforaminal lumbar interbody fusion), 45 pacientes operados por artrodesis lumbar intersomática por vía posterior (PLIF, posterior lumbar interbody fusion) y 42 pacientes operados por artrodesis intersomática lumbar transforaminal (TLIF, transforaminal lumbar interbody fusion) abierta. Resultados: Cuatro pacientes presentaron durotomía incidental, dos del grupo TLIF y dos del grupo PLIF. No hubo casos de durotomía incidental en el grupo de abordaje transforaminal mínimamente invasiva. Ninguno de los pacientes estudiados de los tres grupos presentó posición inadecuada del tornillo, el promedio de sangrado más bajo fue para el grupo de mínima invasión al instrumentar uno y dos niveles. Hubo 6,6\% de infecciones en el grupo PLIF y ninguna en los otros dos grupos. Conclusiones: Las técnicas de artrodesis no están exentas de complicaciones, sin embargo, la frecuencia es menor en las técnicas mínimamente invasivas. De cualquier manera requiere de entrenamiento y no exime la necesidad de tener una curva de aprendizaje para el cirujano de columna, en comparación con las técnicas de fusión lumbar abiertas.

Descriptores: Espondilolistesis; Degeneración del disco intervertebral; Descompresión quirúrgica; Artrodesis.

\section{INTRODUCTION}

Spinal instability is the loss of the spine's ability to maintain the relationship between the vertebrae under physiological strain and to avoid injury to the spinal cord and the nerve roots. Chronic instability is a consequence of progressive deformity that can cause neurological deterioration. 
Theoretically, approaches that respect more the nature of the posterior ligament complex, such as the open transforaminal and minimally invasive approaches, have fewer complications, since the access route through the lumbar muscle masses dissects only fascias and exposes neural elements like the meninges and the nerve roots to less risk. However, in the management of intervertebral discs, they imply a greater demand during transpedicular fixation.

\section{METHOD}

This is an observational, retrospective, cross-sectional, and analytical study. The study was evaluated and approved by the Institutional Review Board of the Hospital Central Norte de Petróleos Mexicanos. There are no conflicts of an ethical nature according to the Declaration of Helsinki or in terms of internal hospital regulations, and the study protocol was explained in detail to the patients included in the study, who signed the informed consent form at the beginning of the study. The Hospital Central Norte project number is 2789-B.

We studied 132 patients who underwent surgery during the eightyear period from January, 2006 to February, 2014. They were divided into three groups by route of surgical access: Group A) Minimally Invasive Transforaminal Lumbar Interbody Fusion (MI-TLIF) with 45 patients (34.09\%), Group B) Posterior Lumbar Interbody Fusion (PLIF) with 45 patients (34.09\%), and Group C) Open Transforaminal Lumbar Interbody Fusion (TLIF) with 42 patients (31.81\%) with a diagnosis of advanced disc degeneration and grade I and II spondylolisthesis.

The results were collected for transoperative bleeding and the most frequent complications, which were incidental durotomy, poor screw placement, and the incidence of infection from the immediate postoperative period to two weeks following surgery.

Of the total 132 patients who underwent surgery, $41 \%$ were female and $59 \%$ were male (Table 1). Patients from 20 to 80 years of age were included, with an average age of 55.5 years (ranging from 26-79 years, standard deviation 11.2 years) (Table 2 ). The minimally invasive transforaminal access group had an average age of 50.7 years (ranging from 26-76 years of age, standard deviation 11.2 years). The posterior access group had an average age of 60.9 years (ranging from 30-79 years of age, standard deviation 9.6 years). The open transforaminal group had an average age of 54.9 years (ranging from 30-77 years of age, standard deviation 10.6 years).

The average total surgical time for the three groups was 230 minutes (SD: 64 minutes), with the minimally invasive transforaminal group averaging 235 minutes (SD: 45 minutes), the posterior access group averaging 228 minutes (SD: 80 minutes), and the open transforaminal group averaging 228 minutes (SD: 64 minutes) with a statistical significance of $p=0.366$ (Figure 1).

Instrumentation was performed at one level in $42.2 \%$ (56) and at two levels in $57.78 \%$ (76) of the patients (Table 3).

Table 1. Patient distribution by sex.

\begin{tabular}{c|c|c|c|c}
\hline & MITLIF & PLIF & TLIF & Total \\
\hline Male & $38.88 \%$ & $20.37 \%$ & $40.74 \%$ & $40.90 \%$ \\
\hline & $(n=21)$ & $(n=11)$ & $(n=22)$ & $(n=54)$ \\
\hline Female & $30.76 \%$ & $43.58 \%$ & $25.64 \%$ & $59.09 \%$ \\
\hline & $(n=24)$ & $(n=34)$ & $(n=20)$ & $(n=78)$ \\
\hline Total & $34.09 \%$ & 34.09 & $31.81 \%$ & $100.00 \%$ \\
\hline & $(n=45)$ & $(n=45)$ & $(n=42)$ & $(n=132)$ \\
\hline
\end{tabular}

Table 2. Age by surgical approach.

\begin{tabular}{c|c|c|c|c}
\hline & MITLIF & PLIF & TLIF & Total \\
\hline Range & $26-76$ & $30-79$ & $30-77$ & $26-79$ \\
\hline Average & 50.73333 & 60.97778 & 54.95238 & 55.56818 \\
\hline Standard deviation & 11.27023 & 9.618847 & 10.67925 & 11.29763 \\
\hline
\end{tabular}

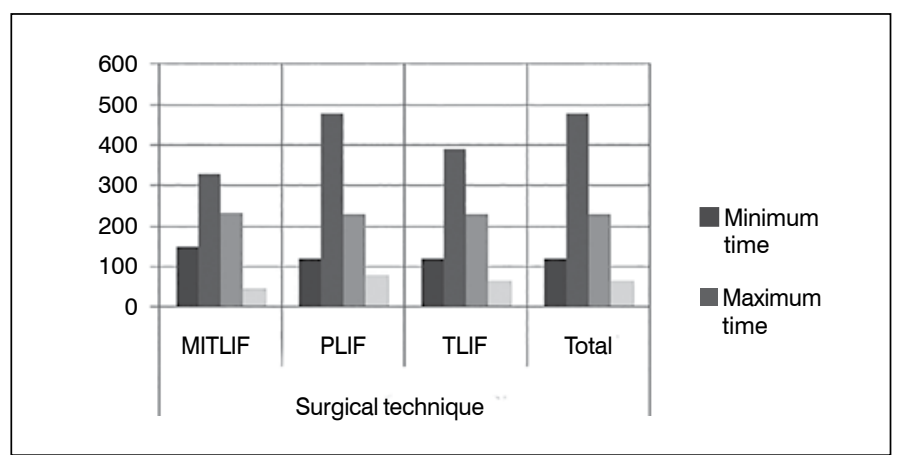

Figure 1. Surgical time by arthrodesis group

Table 3. Surgical time by arthrodesis group.

\begin{tabular}{c|c|c|c|c}
\hline & MITLIF & PLIF & TLIF & Total \\
\hline Range & $150-330$ & $120-480$ & $120-390$ & $120-480$ \\
\hline Average & 235.1111 & 228.6667 & 228.5714 & 230.8333 \\
\hline SD & 45.50835 & 80.21562 & 64.22413 & 64.47725 \\
\hline
\end{tabular}

\section{RESULTS}

The average bleeding (Table 4) of the patients instrumented at one level was $543.3 \mathrm{ml}$, with an average of $136.6 \mathrm{ml}$ in the Ml-TLIF group, an average of $1050 \mathrm{ml}$ in the PLIF group, and an average of $443.3 \mathrm{ml}$ in the TLIF group. The patients instrumented at two levels presented average bleeding of $624.6 \mathrm{ml}$, with an average of $196.6 \mathrm{ml}$ in the MI-TLIF access group, and average of $1231 \mathrm{ml}$ in the PLIF group, and an average of $446.2 \mathrm{ml}$ for the TLIF approach. (Figure 2)

Of the 132 patients who underwent spinal instrumentation surgery, only 5.3\% (7 patients) presented complications. Incidental durotomy occurred in two patients (4.4\%) in the posterior approach arthrodesis (PLIF) group and in two patients $(4.76 \%)$ in the open transforaminal approach (TLIF) group. There were no cases of incidental durotomy in the minimally invasive transforaminal approach (MI-TLIF) group in this study.

Infections occurred in $2.27 \%$ of the patients (3 patients), all of them operated via posterior lumbar access (6.6\% of the 45 patients in this group) and there were no infections resulting from the other access methods (99.33\%, 129 patients). The statistical significance was $p=0.23$ at a confidence interval of $95 \%$. None of the patients in the study presented improper screw placement (Table 5, Figure 3).

\section{DISCUSSION}

In this work, we analyze the open transforaminal approach developed by Harms and Jeszensky, ${ }^{1}$ which is a variant of the posterior lumbar approach described by Cloward in 1953 (apud

Table 4. Bleeding by surgical technique.

\begin{tabular}{c|c|c|c|c}
\hline & MITLIF & PLIF & TLIF & Total \\
\hline Range & $50-300$ & $100-5600$ & $300-1600$ & $50-5600$ \\
\hline Average & 156.6667 & 1077.778 & 445.2381 & 562.5 \\
\hline SD & 58.9684 & 1129.69 & 203.5686 & 771.347 \\
\hline
\end{tabular}

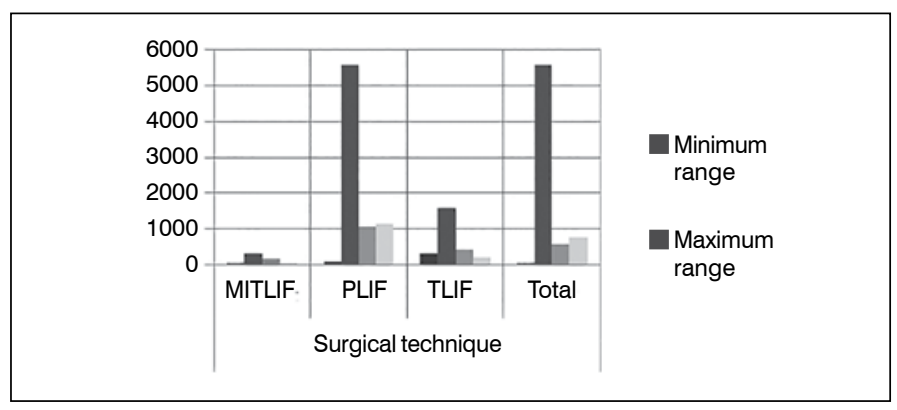

Figure 2. Bleeding by surgical technique. 
Table 5. Complications by surgical technique.

\begin{tabular}{c|c|c|c|c}
\hline Complications & MITLIF & PLIF & TLIF & Total \\
\hline Patients with infection & $0.00 \%$ & $6.60 \%$ & $0.00 \%$ & $2.27 \%$ \\
\hline Number of patients & 0 & 3 & 0 & 3 \\
\hline Patients without infection & $100.00 \%$ & $93.33 \%$ & $100.00 \%$ & $97.73 \%$ \\
\hline Number of patients & 45 & 42 & 42 & 129 \\
\hline $\begin{array}{c}\text { Improper positioning of the } \\
\text { screw }\end{array}$ & $0.00 \%$ & $0.00 \%$ & $0.00 \%$ & $0.00 \%$ \\
\hline Number of patients & 0 & 0 & 0 & 0 \\
\hline $\begin{array}{c}\text { Proper positioning of the } \\
\text { screw }\end{array}$ & $100.00 \%$ & $100.00 \%$ & $100.00 \%$ & $100.00 \%$ \\
\hline Number of patients & 45 & 45 & 42 & 132 \\
\hline With incidental durotomy & $0.00 \%$ & $4.40 \%$ & $4.76 \%$ & $3.03 \%$ \\
\hline Number of patients & 0 & 2 & 2 & 4 \\
\hline Without incidental durotomy & $100.00 \%$ & $95.60 \%$ & $95.24 \%$ & $96.97 \%$ \\
\hline Number of patients & 45 & 43 & 40 & 128 \\
\hline $\begin{array}{c}\text { Total complications by surgical } \\
\text { technique }\end{array}$ & $0 \%(0)$ & $\begin{array}{c}11.1 \% \\
(5)\end{array}$ & $4.76 \%(2)$ & $5.3 \%(7)$ \\
\hline
\end{tabular}

Yan et al. $^{2}$ and Mura et al.), ${ }^{3}$ as well as the minimally invasive transforaminal approach, which offers a suitable access for 360 degree fusion at the lumbar level in cases of degenerative instability, initially reported by Foley and Gupta in $2001^{4}$ with a posterior approach and later with transforaminal approach, as described by Isaacs et al. ${ }^{5}$ and Schwender et al. ${ }^{6}$

The objectives of intervertebral fusion at the lumbar level are to achieve lumbar segmental stability, to decompress the nerve structures, and to reconstruct the height of the intervertebral space in the translational and rotational planes. In our working sample, transpedicular instrumentation was performed at one (42.2\%) and two (57.5\%) lumbosacral levels for advanced disc degeneration and Meyerding grade I and II spondylolisthesis.

Minimally invasive techniques have emerged with a lower frequency of complications. ${ }^{7}$ In our study, there were 7 patients $(5.3 \%)$ with complications secondary to the surgical approach: 3 posterior access infections (6.6\%), 2 open transforaminal approach durotomies (TLIF $=4.4 \%$ ), and two more in the posterior access group $(\mathrm{PLIF}=4.76 \%)$, with no complications in the minimally invasive technique group $(\mathrm{Ml}-\mathrm{TLIF}=0 \%)$ and a statistical significance of $\mathrm{p}<0.23$.
A reduction in the relative risk $(\mathrm{RM})$ of infection was calculated for the minimally invasive (MI-TLIF, $p<0.20$ ) and open transforaminal (TLIF, $p<0.23$ ) approaches, of incidental durotomy for the minimally invasive transforaminal (MI-TLIF, $\mathrm{p}<0.14$ ) approach, and of poor screw placement $(p=0)$. There were increases in the relative risks of infection and incidental durotomy in the posterior approach by factors of 1.56 and 2.00 , respectively.

Minimally invasive techniques have reduced transoperative bleeding to a minimum. ${ }^{8,9}$ A study conducted by Schwender of 120 patients who underwent minimally invasive transforaminal access surgeries reported average bleeding of $140 \mathrm{ml}$ (ranging from 50-450 $\mathrm{ml}$ ) with an average surgical time of 240 minutes (ranging from 110-30 minutes). ${ }^{9,10}$ In our study, we had an average bleeding of $156.6 \mathrm{ml}$ (ranging from 50-330 ml) for minimally invasive transforaminal (MlTLIF) arthrodesis, as compared to the open techniques. The classic transforaminal route had an average bleed of $445.2 \mathrm{ml}$ (ranging from 300-1600 ml, with an average surgical time of 235 minutes), while the posterior approach (PLIF) had an average bleed of 1077.7 $\mathrm{ml}$ (ranging from 100-5600), with a statistical significance of $p=0$ (confidence interval of 95\%).

The minimally invasive transforaminal approach had fewer complications and less bleeding, both statistically significant, as compared to the open transforaminal and posterior approaches.

\section{CONCLUSION}

Minimally invasive transforaminal lumbar interbody fusion (MI-TLIF) resulted in a statistically significant lower bleeding volume as compared to the open transforaminal (TLIF) and posterior (PLIF) interbody fusion techniques.

Performing minimally invasive techniques requires training and does not eliminate the need for a learning curve for the spine surgeon, as compared to open lumbar fusion techniques, which are more accessible and technically less demanding. Although minimally invasive lumbar arthrodesis techniques are more expensive, their risk-benefit seems to be more favorable.

All the authors declare that there are no potential conflicts of interest regarding this article.

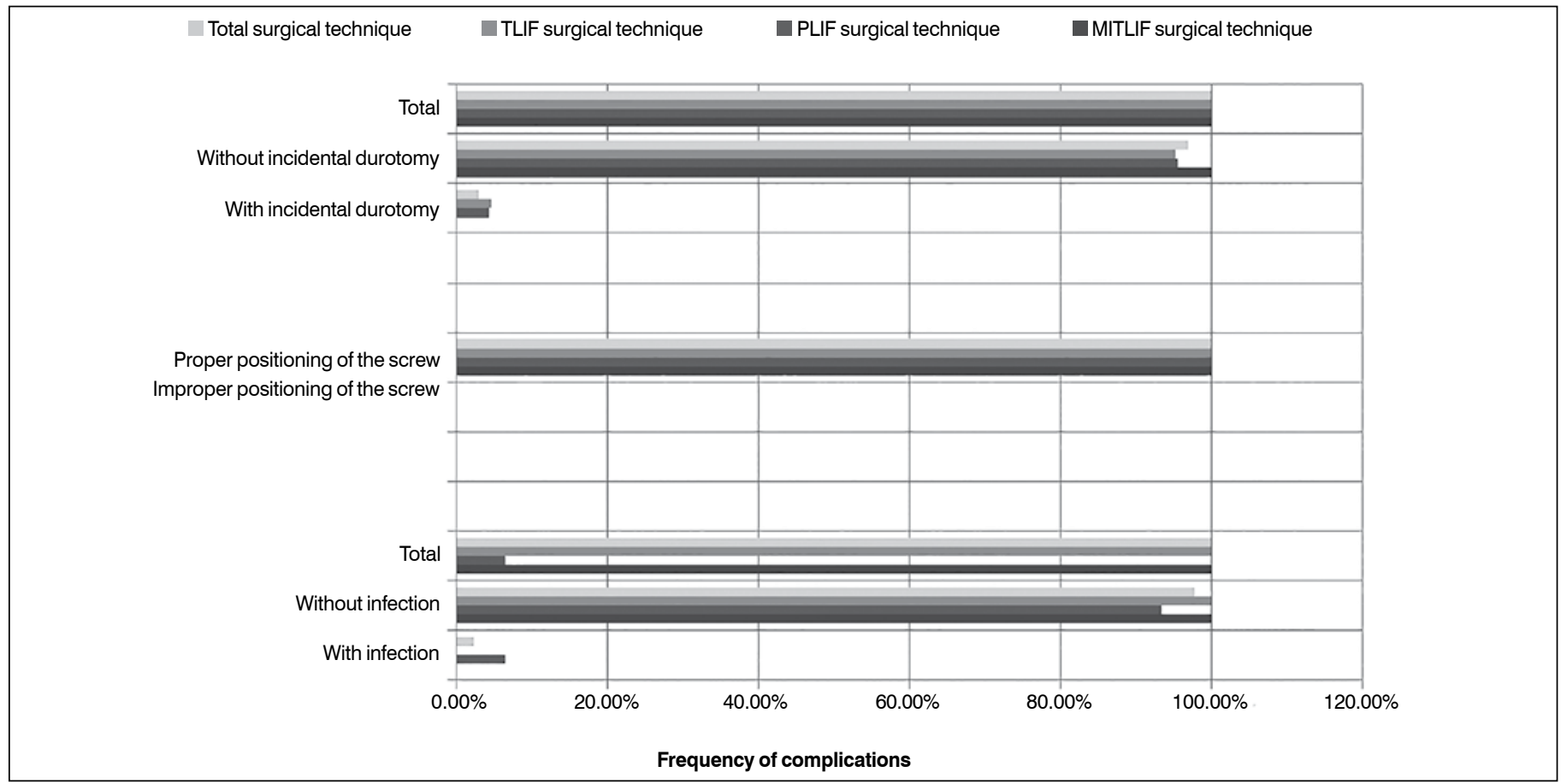

Figure 3. Complications by surgical technique. 
CONTRIBUTIONS OF THE AUTHORS: Each author played an important in the development of the manuscript. AAM was the principal author of the article. RRB and MLL were coauthors, surgeons, and reviewers of the text. SPVA reviewed the statistics and methodology of the article.

\section{REFERENCES}

1. Harms JG, Jeszenszky D. The unilateral transforaminal approach for posterior lumbar interbody fusion. Orthop Traumatol. 1998;6(2):88-9.

2. Yan DL, Pei FX, Li J, Soo CL. Comparative study of PILF and TLIF treatment in adult degenerative spondylolisthesis. Eur Spine J. 2008;17(10):1311-6.

3. Mura PP, Costaglioli M, Piredda M, Caboni S, Casula S. TLIF for symptomatic disc degeneration: a retrospective study of 100 patients. Eur Spine J. 2011;20(Suppl 1):S57-60.

4. Foley KT, Gupta SK, Justis JR, Sherman MC. Percutaneous pedicle screw fixation of the lumbar spine. Neurosurg Focus. 2001;10(4):E10.

5. Isaacs RE, Podichetty VK, Santiago P, Sandhu FA, Spears J, Kelly K, et al. Minimally invasive microendoscopy-assisted transforaminal lumbar interbody fusion with instrumentation. J Neurosurg Spine. 2005;3(2):98-105.

6. Schwender JD, Holly LT, Rouben DP, Foley KT. Minimally invasive transforaminal lumbar interbody fusion (TLIF): technical feasibility and initial results. J Spinal Disord Tech.
2005:18(Suppl):S1-6.

7. Villavicencio AT, Burneikiene S, Roeca CM, Nelson EL, Mason A. Minimally invasive versus open transforaminal lumbar interbody fusion. Surg Neurol Int. 2010;1:12.

8. Shunwu F, Xing Z, Fengdong Z, Xiangqian F. Minimally invasive transforaminal lumbar interbody fusion for the treatment of degenerative lumbar diseases. Spine (Phila Pa 1976). 2010;35(17):1615-20

9. Lawton CD, Smith ZA, Barnawi A, Fessler RG. The surgical technique of minimally invasive transforaminal lumbar interbody fusion. J Neurosurg Sci. 2011;55(3):259-64.

10. Adogwa O, Parker SL, Bydon A, Cheng J, McGirt MJ. Comparative effectiveness of minimally invasive versus open transforaminal lumbar interbody fusion: 2-year assessment of narcotic use, return to work, disability, and quality of life. J Spinal Disord Tech. 2011;24(8):479-84. 